The 16th Economic International Conference

New Challenges and Opportunities for the Economy 4.0, May 7-8th, 2020, Suceava, Romania

\title{
European Structural Funds and Rentability
}

\author{
Andrei-Alexandru MOROŞAN
}

https://doi.org/10.18662/lumproc/ncoe4.0.2020/32

How to cite: Moroşan, A.-A. (2020). European Structural Funds and Rentability. In C. Nastase (vol. ed.), Lumen Proceedings: Vol. 13. 16th Economic International Conference NCOE 4.02020 (pp. 358-367). Iasi, Romania: LUMEN Publishing House.

https://doi.org/10.18662/lumproc/ncoe4.0.2020/32 


\title{
European Structural Funds and Rentability
}

\author{
Andrei-Alexandru MOROŞAN ${ }^{1}$
}

\begin{abstract}
One of the great achievements of the European Union is the creation of the single market, but for it to work efficiently, it is imperative that the gaps between the participating states be minimal. Thus, to address this issue the EU has created a Regional Development Policy through which it allocates Structural and Cohesion Funds to finance projects in countries with lower economic development. Lately there is an increasingly fierce debate on the efficiency of structural funds for EU members in Central and Eastern Europe. This debate is fueled by various studies that show that although many of the projects financed from Structural Funds achieve their objectives, the effects are not visible in the aggregate indicators.

Within this article we intend to analyze the impact that the Structural Funds have on the profitability of the beneficiary companies. For this we analyzed a group of companies that benefited from non-reimbursable financial aid during the multiannual financial period 2007-2013 and a group of companies that did not benefit from this facility. Following the analysis of the financial accounting data reported by the companies in the two groups, statistically significant differences were identified.
\end{abstract}

Keywords: Structural Funds; Rentability; Turnover; Financial analysis.

\footnotetext{
1"Stefan cel Mare” University, Suceava, Romania, alexandrumorosan@gmail.com. 


\section{Introduction}

Since the first wave of enlargement, the European Commission has realized that it is necessary to create tools to support new members. For the European single market to function effectively, it was imperative to eliminate all the economic gaps between the participating countries. Thus, the European Commission has created the Regional Development Policy which addresses the regions that have a GDP per capita below the EU average. These regions benefit from structural and cohesion funds to finance various types of projects [7]. The areas of intervention are very versatile, through these non-reimbursable financial aids the regions are able to finance infrastructure projects, projects for improving the efficiency of public services, educational and human resources training projects and projects for developing the business environment.

The issue of Regional Development Policy became much more complicated after the enlargements of the EU in 2004 and 2007 when several countries with large differences in economic development were accepted as new members. If until 2004 the countries that joined the EU had a GDP per capita of at least of $70 \%$ of the EU average, in 2004 countries with a GDP per capita of $20 \%$ of the EU average were admitted [1].

Given the very large differences between the countries that joined the EU until 2004 and those that joined the EU after this year, the logical question arises whether the Regional Development Policy can meet the specific needs of these new members after 2004.

\section{Literary Review}

One of the researchers who approached the field of structural funds is Peter Wostner, who has several published works that analyze the process from different perspectives, trying to quantify the effects that these financial resources have. The author identifies an impact conditioned by the management practices and the institutional absorption system in the Member State [8]. Peter Wostner is also concerned with analyzing the institutional system and the factors that may affect it, identifying several indicators that could affect the implementation process [9].

Aiste Palevičiene and Daiva Dumčiuvienè are also authors concerned with this problem, the two researchers realize the limitations of the quantification based only on the GDP growth or GDP per capita, so they propose that the impact of the structural funds be quantified by a wide range of socio-economic, environmental and educational indicators [6]. 
The authors Frank Barry, John Bradley and Aoife Hannan, have a more reserved approach in quantifying the impact of structural funds. They believe that structural funds have a long-term impact, only through investments in the development of infrastructure and human capital, which have a direct effect on increasing productivity and profitability in the business environment [2].

Another research with important contributions to this field is the one by Daiva Jureviciene and Jürate Pileckaite published in 2013. This research is conducted at the microeconomic level and analyzes how economic enterprises approach the opportunity for financial aid. Research shows that businesses do not have a rational behavior when it comes to these non-reimbursable financial aids; companies are willing to implement even secondary projects, which were not a priority, only to benefit from non-repayable financial grants. Another practice identified is that of overestimating both the costs and the production capacity required in the design phase of projects with non-reimbursable financial aid [3].

\section{Methodology}

Considering that the literature does not reach a consensus regarding the impact generated by the structural funds and the fact that some authors have even claimed that the structural funds addressed to the business environment determine companies to have an irrational behavior, the hypothesis of the present study is that the structural funds increase the profitability of the beneficiary companies. At the theoretical level this hypothesis is very easy to accept, the companies that benefit from nonreimbursable financial aid make investments in physical assets that should have a noticeable effect on the obtained production and from the financial perspective, they have to bear only part of the financing cost.

In order to be able to prove this hypothesis, we proceeded to identify the companies that benefited from non-reimbursable financial aid during the multiannual exercise 2007-2013 (Group 1). The analysis was performed at the level of the North-East Region of Romania, which is the poorest in terms of GDP per capita at the level of Romania, so the effect of the non-reimbursable funds should be very easy to identify. For all these companies, the annual financial statements were extracted from the website of the Ministry of Finance [11] for the period 2005-2018. In order to have a comparison basis, we also formed a control group of companies that did not receive financial aid (Group 2). By comparative analysis of the financial 
accounting data of the two groups we will be able to confirm or infirm the stated hypothesis.

\section{Case Study}

A first indicator that we will analyze is the evolution index of the Turnover. To facilitate the analysis process we will eliminate the extreme values using the interquartile range method, with a coefficient of 3 , thus eliminating the values greater than 2.9461 and lower than -0.6324, so we obtain a normal distribution that will allow the application statistical variation tests.

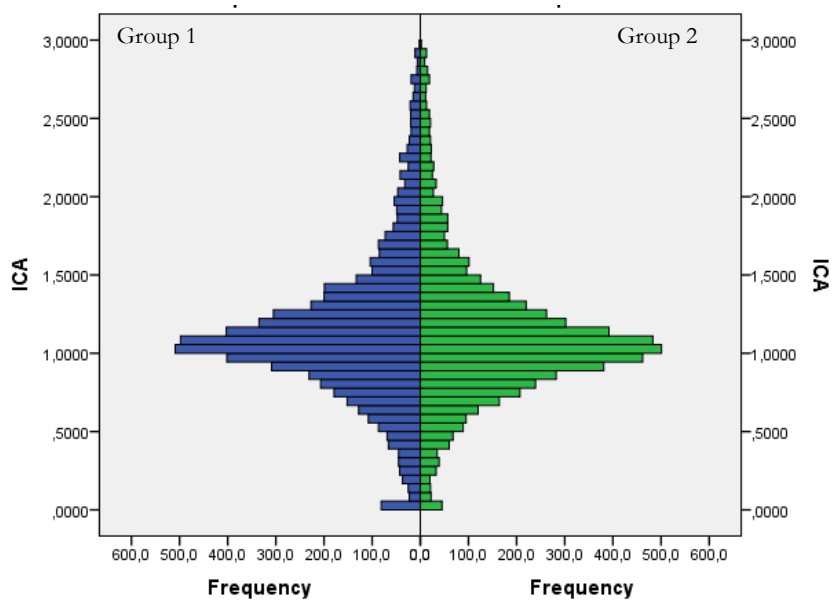

Figure 1 -Distribution of the Evolution Index of the turnover: Gr 1 vs Gr 2

Source: Data processed by the author (www.fonduri-ue.ro and www.mfinante.ro)

Analyzing the shape of the two distributions presented in Figure 1, we find that there are no notable differences between the two groups. The central tendency for both groups is around 1.

Table 1 - Group Statistics

\begin{tabular}{|c|l|l|l|l|l|}
\hline & \multicolumn{1}{|c|}{ GRUP } & \multicolumn{1}{c|}{ N } & \multicolumn{1}{c|}{ Mean } & Std. Deviation & Std. Error Mean \\
\hline \multirow{2}{*}{ ICA } & Analyzed Group (1) & 6093 & 1,144784 &, 4884981 &, 0062582 \\
\cline { 2 - 6 } & Control Group (2) & 5923 & 1,129749 &, 4677930 &, 0060783 \\
\hline
\end{tabular}

Source: Data processed by the author (www.fonduri-ue.ro and www.mfinante.ro)

For the period 2005-2018 for the group of companies that benefited from non-refundable financial aid, the group average was 1.144784, which means that these companies registered an average annual growth of $14.47 \%$, while the companies in the control group had registered an average annual growth of $12.97 \%$. 
Table 2 - Independent Samples Test

\begin{tabular}{|c|c|c|c|c|c|c|c|c|c|}
\hline & \multicolumn{2}{|c|}{$\begin{array}{c}\text { Levene's Test for } \\
\text { Equality of } \\
\text { Variances }\end{array}$} & \multicolumn{7}{|c|}{ t-test for Equality of Means } \\
\hline & \multirow[t]{2}{*}{ F } & \multirow[t]{2}{*}{ Sig. } & \multirow[t]{2}{*}{$\mathrm{t}$} & \multirow[t]{2}{*}{ df } & \multirow{2}{*}{$\begin{array}{c}\text { Sig. (2- } \\
\text { tailed) }\end{array}$} & \multirow{2}{*}{$\begin{array}{c}\text { Mean } \\
\text { Difference }\end{array}$} & \multirow{2}{*}{$\begin{array}{l}\text { Std. Error } \\
\text { Difference }\end{array}$} & \multicolumn{2}{|c|}{$\begin{array}{c}95 \% \text { Confidence Interval } \\
\text { of the Difference }\end{array}$} \\
\hline & & & & & & & & Lower & Upper \\
\hline \begin{tabular}{|l|l} 
& $\begin{array}{l}\text { Equal variances } \\
\text { assumed }\end{array}$ \\
\end{tabular} & 9,993 &, 002 & 1,722 & 12014 &, 085 &, 0150348 & 0087295 & -0020764 & 0321460 \\
\hline ICA $\begin{array}{l}\text { Equal variances } \\
\text { not assumed }\end{array}$ & & & 1,723 & 12011,296 & 085 &, 0150348 &, 0087241 &,- 0020659 & ,0321355 \\
\hline
\end{tabular}

Source: Data processed by the author (www.fonduri-ue.ro and www.mfinante.ro)

Applying a comparison test of the mean, we find that the difference between the two groups is not statistically representative, practically the nonreimbursable financial aid did not have a noticeable effect on the evolution of the Turnover.

The fact that the difference between the two groups is not statistically representative, can be attributed to the fact that the time horizon taken in the analysis is too large, so we will try to apply the test for a narrower period.

For the group of companies that benefited from non-reimbursable financial aid, we will consider only the operating period, that is, the results obtained from the years following the completion of the project, and for the control group we will only consider the financial accounting data registered after 2009 (this value was selected because the majority of the analyzed projects were completed until this year).

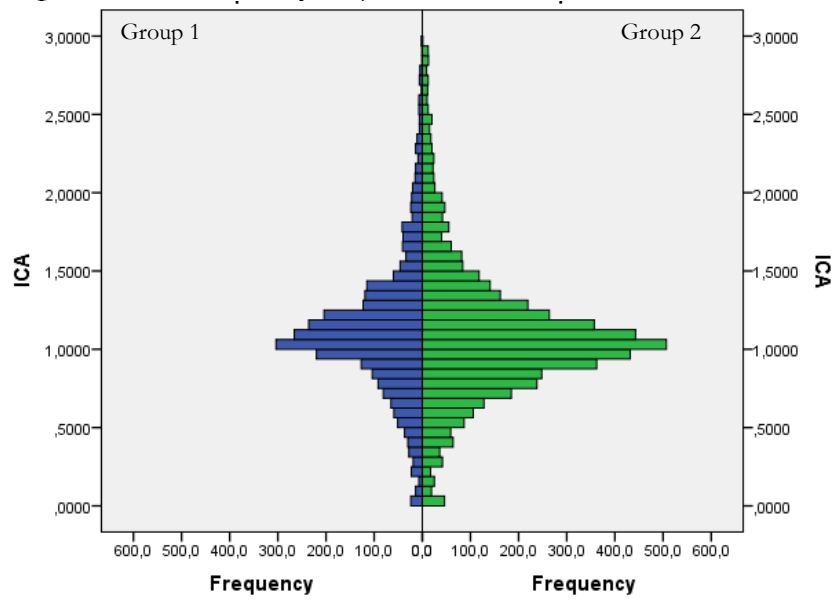

Figure 2-Distribution of the Evolution Index of the turnover: Gr 1 vs Gr2

Source: Data processed by the author (www.fonduri-ue.ro and www.mfinante.ro) 
Similar to the period analyzed above, the obtained distributions (Figure 2) have similar forms, the central tendency being around 1, which indicates that there were no very large variations in the analyzed time interval.

Table 3 - Group Statistics

\begin{tabular}{|l|l|l|l|l|l|}
\hline \multirow{2}{*}{ ICA } & GRUP & $\mathrm{N}$ & Mean & Std. Deviation & Std. Error Mean \\
\cline { 2 - 6 } & Analyzed Group (1) & 2804 & 1,123651 &, 4397812 &, 0083052 \\
\hline
\end{tabular}

Source: Data processed by the author (www.fonduri-ue.ro and www.mfinante.ro)

Following the calculation of the central tendency indicators we find that the arithmetic averages are similar, for the group of companies that benefited from non-reimbursable financial aid we obtain an average annual growth of $12.36 \%$, and for the control group $10.55 \%$.

Table 4 - Independent Samples Test

\begin{tabular}{|c|c|c|c|c|c|c|c|c|c|c|}
\hline & \multicolumn{9}{|c|}{$\begin{array}{l}\text { Levene's Test fort-test for Equality of Means } \\
\text { Equality of Variances }\end{array}$} \\
\hline & & \multirow[t]{3}{*}{$\mathrm{F}$} & \multirow[t]{3}{*}{ Sig. } & \multirow[t]{3}{*}{ t } & \multirow[t]{3}{*}{ df } & \multirow{3}{*}{$\begin{array}{l}\text { Sig. }(2 \\
\text { tailed) }\end{array}$} & \multirow{3}{*}{$\begin{array}{l}\text { Mean } \\
\text { Difference }\end{array}$} & \multirow{2}{*}{\multicolumn{3}{|c|}{$\begin{array}{l}\text { Std. Error } 95 \% \text { Confidence } \\
\text { Difference }\end{array}$}} \\
\hline & & & & & & & & & & \\
\hline & & & & & & & & & Lower & Upper \\
\hline & $\begin{array}{l}\text { Equal variances } \\
\text { assumed }\end{array}$ & 1,608 &, 205 & 1,705 & 7807 &, 088 &, 0181315 &, 0106331 &,- 0027123 &, 0389754 \\
\hline & $\begin{array}{l}\text { Equal variances } \\
\text { not assumed }\end{array}$ & & & 1,724 & 5989,864 &, 085 &, 0181315 &, 0105199 &,- 0024913 & 0387544 \\
\hline
\end{tabular}

Source: Data processed by the author (www.fonduri-ue.ro and www.mfinante.ro)

Applying a comparison test of the mean we find that even in this narrower period the difference between the averages is not statistically representative (Sig.> 0.05) so we can conclude that the structural funds do not have an observable effect on the turnover.

Another indicator which we will analyze is the index of evolution of the rate of return. Similar to the turnover index, we have eliminated the extreme values, using the interquartile range method, with a coefficient of 3 , thus eliminating values greater than 6.0674 and lower than -4.2674 . 


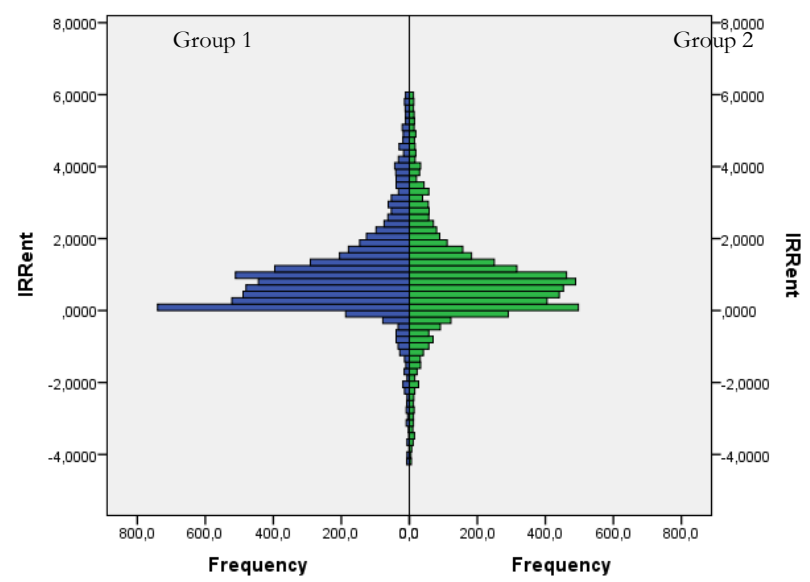

Figure 3 -Distribution of the Evolution Index of the rate of return: Gr. 1 vs Gr. 2 Source: Data processed by the author (www.fonduri-ue.ro and www.mfinante.ro)

Graphically representing the obtained distributions (Figure 3) we find that there are certain differences between the two groups. Positive values are most frequently recorded among companies that have received non-reimbursable financial aid.

Table 5 - Group Statistics

\begin{tabular}{|l|l|l|l|l|l|}
\hline & GRUP & $\mathrm{N}$ & Mean & Std. Deviation & Std. Error Mean \\
\hline \multirow{2}{*}{ IRRent } & Analyzed Group (1) & 5903 &, 977319 & 1,2936253 &, 0168373 \\
\cline { 2 - 6 } & Control Group (2) & 5558 &, 833899 & 1,3883845 &, 0186230 \\
\hline
\end{tabular}

Source: Data processed by the author (www.fonduri-ue.ro and www.mfinante.ro)

Determining the average at the level of the two groups we find that the mean of the period is sub unitary for the both sub-collectivities. For the period 2005-2018, the companies that benefited from non-reimbursable financial aid registered an average annual decrease of $2.26 \%$ of the rate of return, while the companies that did not receive community support registered an average annual decrease of $16.61 \%$.

Table 6 - Independent Samples Test

\begin{tabular}{|c|c|c|c|c|c|c|c|c|c|c|}
\hline & \multicolumn{2}{|c|}{$\begin{array}{c}\text { Levene's Test } \\
\text { for Equality of } \\
\text { Variances }\end{array}$} & \multicolumn{7}{|c|}{ t-test for Equality of Means } \\
\hline & & \multirow[t]{2}{*}{$\mathrm{F}$} & \multirow[t]{2}{*}{ Sig. } & \multirow[t]{2}{*}{$\mathrm{t}$} & \multirow[t]{2}{*}{ df } & \multirow{2}{*}{$\begin{array}{l}\text { Sig. (2- } \\
\text { tailed) }\end{array}$} & \multirow{2}{*}{$\begin{array}{c}\text { Mean } \\
\text { Difference }\end{array}$} & \multirow{2}{*}{$\begin{array}{l}\text { Std. Error } \\
\text { Difference }\end{array}$} & \multicolumn{2}{|c|}{$\begin{array}{c}95 \% \text { Confidence Interva } \\
\text { of the Difference }\end{array}$} \\
\hline & & & & & & & & & Lower & Upper \\
\hline \multirow{2}{*}{ IRRent } & $\begin{array}{l}\begin{array}{l}\text { Equal variances } \\
\text { assumed }\end{array} \\
\end{array}$ & 7,783 & 005 & 5,725 & 11459 & 000 &, 1434204 & 0250527 & 0943128 & 1925280 \\
\hline & $\begin{array}{l}\text { Equal variances not } \\
\text { assumed }\end{array}$ & & & 5,713 & 11266,742 &, 000 &, 1434204 &, 0251060 &, 0942082 &, 1926325 \\
\hline
\end{tabular}

Source: Data processed by the author (www.fonduri-ue.ro and www.mfinante.ro) 
The difference between the average of the two groups (of 14.35\%) is statistically representative, which means that the structural funds [4], [5] have a remarkable effect in terms of increasing the profitability of the beneficiary companies.

Narrowing the analyzed time horizon, only at the postimplementation period (for the group of companies that have received nonreimbursable financial aid) and for the period 2009-2018 (for the control group) we find that the differences are more pronounced.

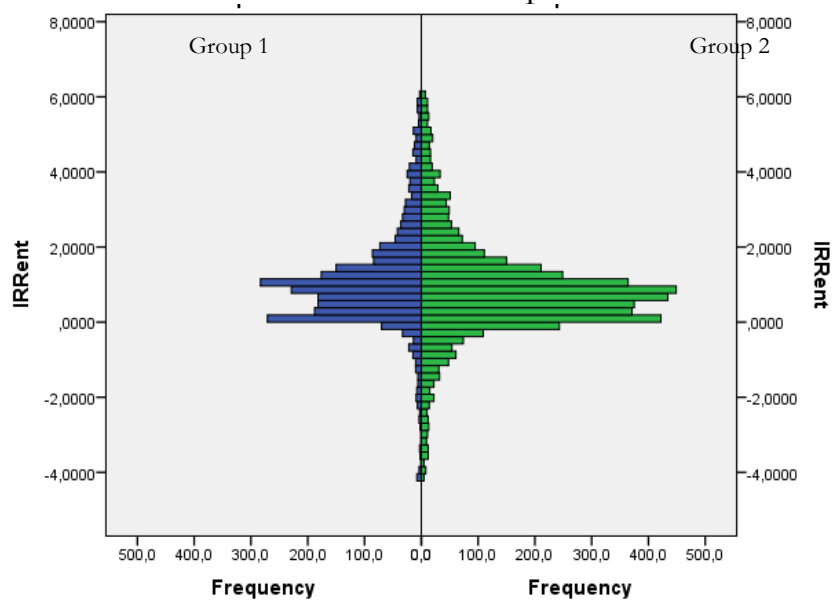

Figure 4 -Distribution of the Evolution Index of the rate of returns: Gr 1 vs Gr 2 Source: Data processed by the author (www.fonduri-ue.ro and www.mfinante.ro)

From Figure 4, we can see that for the analyzed group (1) the number of enterprises that register decreases in the rate of return is much smaller compared to the control group (2) and the period analyzed previously.

Table 7 -Group Statistics

\begin{tabular}{|l|l|l|l|l|l|}
\hline \multirow{2}{*}{} & GRUP & $\mathrm{N}$ & Mean & Std. Deviation & Std. Error Mean \\
\hline \multirow{2}{*}{ IRRent } & Analyzed Group (1) & 2548 & 1,103253 & 1,3514286 & 0267728 \\
\cline { 2 - 6 } & Control Group (2) & 4676 &, 858810 & 1,3966631 &, 0204246 \\
\hline
\end{tabular}

Source: Data processed by the author (www.fonduri-ue.ro and www.mfinante.ro)

From the analysis of the media of the two groups we find that for the analyzed group the average of the evolution index is super unitarian, indicating an increase, while for the control group the media is sub unitary. On average, after the implementation of the projects with non-reimbursable financing, the companies registered an average annual increase in the rate of return of $10.32 \%$, while the control group registered a decrease of $14.12 \%$. 
Table 8 - Independent Samples Test

\begin{tabular}{|c|c|c|c|c|c|c|c|c|c|c|}
\hline & \multicolumn{2}{|c|}{$\begin{array}{c}\text { Levene's Test for } \\
\text { Equality of Variances }\end{array}$} & \multicolumn{7}{|c|}{ t-test for Equality of Means } \\
\hline & & \multirow[t]{2}{*}{ F } & \multirow[t]{2}{*}{ Sig. } & \multirow[t]{2}{*}{$\mathrm{t}$} & \multirow[t]{2}{*}{ df } & \multirow{2}{*}{$\begin{array}{l}\text { Sig. (2- } \\
\text { tailed) }\end{array}$} & \multirow{2}{*}{$\begin{array}{c}\text { Mean } \\
\text { Difference }\end{array}$} & \multirow{2}{*}{$\begin{array}{l}\text { Std. Error } \\
\text { Difference }\end{array}$} & \multicolumn{2}{|c|}{$\begin{array}{c}95 \% \text { Confidence Interva } \\
\text { of the Difference }\end{array}$} \\
\hline & & & & & & & & & Lower & Upper \\
\hline \multirow{2}{*}{ IRRent } & $\begin{array}{l}\text { Equal variances } \\
\text { assumed }\end{array}$ &, 461 & 497 & 7,189 & 7222 &, 000 & 2444435 & 0340022 & ,1777891 & 3110978 \\
\hline & $\begin{array}{l}\text { Equal variances } \\
\text { not assumed }\end{array}$ & & & 7,259 & 5381,351 &, 000 & 2444435 & 0336741 &, 1784285 & 3104584 \\
\hline
\end{tabular}

Source: Data processed by the author (www.fonduri-ue.ro and www.mfinante.ro)

The differences between the averages of the two groups are statistically representative (Sig. $<0.05$ ), thus confirming that the nonreimbursable financial aid has a considerable effect on the profitability of the beneficiary companies.

\section{Conclusion}

Following the analyzes, we find that the stated hypothesis is confirmed, the structural funds contribute to the efficiency of the activities of the beneficiary companies, leading to an increase in their profitability. Although the analysis of the turnover did not result in statistically representative differences at the level of the two groups, the index of evolution of the rate of return shows clear differences between the two categories of enterprises.

The first argument that led to the acceptance of the hypothesis is that at the level of the period 2005-2018 between the group of companies that have benefited from structural funds and those that have not benefited from this financial instrument there are statistically representative differences. The second argument is that after narrowing the time horizon considered in the post implementation period, respectively the period 20092018 for the control group (most of the projects were completed during 2009) we find that the difference between the groups has increased. The analyzed group recorded a super unitary value of the evolution index, while the control group had a sub unitary value, similar to that of the period 20052018. The fact that in the post-implementation period, for the group that benefited from non-reimbursable support, the value of the index of evolution for the rate of return registered a better value, than for the period 2005-2018, and the control group recorded similar values both during 2005 2018 as well as 2009-2018, clearly demonstrates that the non-reimbursable financial aid led to the efficiency of the activity in the majority of the 
beneficiary companies, these registering the increase of the rate of profitability, as a result of the implementation of the European projects.

\section{Acknowledgements}

This work is supported by project POCU 125040, entitled "Development of the tertiary university education to support the economic growth PROGRESSIO", co-financed by the European Social Fund under the Human Capital Operational Program 2014-2020.

\section{References}

[1] Bachtler J \& Taylor S. The added value of the Structural Funds: A regional perspective. IQ-Net Report on the Reform of Structural Funds. Glasgow; 2003.

[2] Barry F Bradley J \& Hannan A. The Single Market, The Structural Funds and Ireland's Recent Economic Growth. Journal of Common Market Studies; 2001 39, (3): 537 - 552.

[3] Jureviciene D Jurate P. "The Impact of EU Structural Fund Support and Problems of its Absorption." Business, Management and Education. 11; 2013, pp. 1-18.

[4]Dumčiuvienè D \& Adomynienė I. The Evaluation of European Union Structural Support. Procedia - Social and Behavioral Sciences; 2014; 156, 382 - 387.

[5] Ederveen S, Groot LH \& Nahuis R. Fertile Soil for Structural Funds? Tinbergen Institute Discussion Paper TI 2002, no. 02-096/3.

[6] Palevičienè A \& Dumčiuvienè D. Socio-Economic Diversity of European Regions: Finding the Impact for Regional Performance. Procedia Economics and Finance, 2015, 23, pp. 1096 - 1101.

[7] Reiner M. The Impact of the EU's Structural and Cohesion Funds on Real Convergence in the EU. NBP conference potential output and barriers to growth Zalesie Górne; 2003.

[8] Wostner P. Micro-efficiency of the EU Cohesion Policy. European Policies Research Center, Glasgow; 2008.

[9] Wostner, P \& Šlander S. The effectiveness of EU cohesion policy revisited: are EU funds really additional? European Policies Research Centre - Research Paper; 2009, Number 69.

Sites:

[10] Romanian Ministry of European Funds. Available from: www.fonduri-ue.ro

[11] Romanian Ministry of Finance. Available from: www.mfinante.ro 